\title{
Prawo handlowe w szwajcarskim Kodeksie zobowiązań
}

I. Kodeks zobowiązań był kamieniem milowym w procesie prawnej unifikacji Szwajcarii. W obliczu głębokich przemian polityczno-gospodarczych w państwach Europy zachodniej w XIX wieku, uchwalenie kodeksu obowiązującego na terytorium całej Konfederacji było z jednej strony koniecznością, z drugiej zaś - zabiegiem obarczonym wysokim ryzykiem. Argumentem przemawiającym za potrzebą uchwalenia ustawy obowiązującej na terytorium całej Konfederacji były przede wszystkim poważne utrudnienia w handlu, które spowalniały tempo rozwoju gospodarczego. Przezwyciężenie tych różnic leżało nie tylko w interesie uprzemysłowionych regionów niemieckojęzycznych, ale w interesie wszystkich kantonów. Stworzenie własnego ponadkantonalnego ustawodawstwa wywołałoby „efekt izolacji”1 od kultur prawnych innych państw europejskich, umacniając tym samym pozycję polityczną Szwajcarii. Potencjał pozytywnych skutków zewnątrzpaństwowych nie przesądzał jednak o obniżeniu ryzyka wystąpienia negatywnych skutków wewnątrz kraju. Od powodzenia stosowania przepisów OR (Obligationenrecht - Prawo zobowiązań) zależały losy dalszego procesu jednoczenia prawnego wszystkich kantonów Szwajcarii. Fiasko pierwszej ogólnoszwajcarskiej kodyfikacji umocniłoby pozycję przeciwników unifikacji i na długi czas ugruntowałoby nastroje decentralistyczne. W przyszłości zaś brak społecznej i gospodarczej jedności wpłynąłby na dalszy byt prawny i państwowy Szwajcarii²

Wraz z uchwaleniem 14 czerwca 1881 roku Prawa zobowiązań ${ }^{3}$ rozpoczął się nieodwracalny proces głębokiego jednoczenia prawnego terytorium

${ }^{1}$ E. Bucher, Hundert Jahre schweizerisches Obligationenrecht: wo stehen wir heute im Vertragsrecht? Referat für den schweizerischen Juristenverein, „Zeitschrift für Schweizerisches Recht” (ZSR), neue Folge 102 II (1983), s. 260.

${ }^{2}$ Ibidem, s. 262.

${ }^{3} \mathrm{~W}$ wersji francuskiej i włoskiej ustawa nosi miano Kodeksu zobowiązań (Code des obligations, Codice dei obligazioni), za: A. Klimaszewska, Code de commerce - Francuski Kodeks Handlowy z 1807 r., Gdańsk 2011, s. 173. 
całej Szwajcarii. Ustawa nie tylko przełamała bariery rozdrobnienia ustawodawczego, ale doprowadziła do zmian ustrojowych polegających na odebraniu kantonom znaczącej części mocy prawodawczej. Szwajcarskie Prawo zobowiązań było dziełem wyjątkowym nie tylko ze względu na jasną i czytelną konstrukcję, a także na prosty język ustawy, ale przede wszystkim ze względu na ucieleśnienie idei code unique, tj. zebrania pod egidą Prawa zobowiązań przepisów obejmujących prawo cywilne i prawo handlowe. Obowiązujący po dziś dzień Kodeks cywilny z 1912 roku (Zivilgesetzbuch - ZGB) w kwestiach zasadniczych czerpał z Prawa zobowiązań z 1881 roku, a w częściowo zmienionej formie, objął jego przepisy swoim zakresem jako piątą księgę Kodeksu cywilnego. Szwajcarskie Prawo zobowiązań było nie tylko dziełem przełomowym dla prawa Szwajcarii, ale stało się także podstawą opracowania innych kodyfikacji cywilnych i handlowych w Europie i na świecie ${ }^{4}$.

II. Pierwsze próby unifikacji prawnej Szwajcarii podjęto już w trakcie prac nad konstytucją $1848 \mathrm{roku}^{5}$. Przedstawiciele Berna i Solury wystąpili z wnioskiem o scentralizowanie procesu karnego, ustawodawstwa handlowego i procesu handlowego ${ }^{6}$. Nie udało im się jednak przeforsować tego wniosku. Wspólny kodeks oznaczał bowiem dla większości przedstawicieli kantonów konieczność odstąpienia od tego, co zaufane, znane i bezpieczne na rzecz niepewnej przyszłości ${ }^{7}$. Prawo ponadkantonalne jawiło się jako narzędzie służące częściowemu ograniczeniu suwerenności kantonalnej, co w kontekście kulturowym Szwajcarii stanowiłoby odejście od głęboko zakorzenionej tradycji prawnego partykularyzmu ${ }^{8}$.

Pomimo że idea stworzenia wspólnej kodyfikacji napotykała znaczący opór, pojawiały się coraz bardziej zdecydowane głosy o potrzebie pokonania rozdrobnienia terytorialnego w prawie. W 1862 roku Basil F. Curti złożył wniosek na posiedzeniu Rady Narodowej o podjęcie niezbędnych środków zmierzających do przyjęcia ogólnoszwajcarskiego kodeksu zobowiązań drogą konkordatu, a jeśli okazałoby się to niemożliwe dla terytorium całej Konfederacji, to o przyjęcie kodeksu drogą konkordatu przez możliwie naj-

${ }^{4}$ E. Bucher, Das Schweizerische Obligationenrecht - ein Markstein und ein Vorbild. Vor 125 Jahren wurde das von Walter Munziger gaschaffene OR verabschiedet, „Neue Zürcher Zeitung”, nr 132, 10/11.06.2006, s. 31.

${ }^{5}$ K. Sójka-Zielińska, Stulecie kodeksu cywilnego szwajcarskiego, „Czasopismo Prawno-Historyczne", T. LXIV, 2/2012, s. 37.

${ }^{6}$ E. Huber, System und Geschichte des Schweizerischen Privatrecht, T. IV, Basel 1893, s. 202.

${ }^{7}$ E. Bucher, Hundert Jahre..., op. cit., s. 261.

${ }^{8}$ Konstytucja Republiki Helweckiej z 14 kwietnia 1798 r. stanowiła, że podstawą orzeczniczą są ustawy kantonalne i zwyczaje do czasu, aż Rady Kantonów będą w stanie uchwalić jednorodne ustawy na całym terytorium. Z kolei Konstytucja z 20 maja 1802 r. stanowiła, że zostanie opracowany kodeks cywilny, którego wejście w życie będzie zależało od decyzji poszczególnych kantonów, [za:] E. Huber, System und Geschichte des Schweizerischen Privatrecht, T. IV, Basel 1893, s. 202-203. 
większą liczbę kantonów ${ }^{9}$. Jeszcze w tym samym roku Rada Federalna powierzyła przygotowanie projektu ustawy prawa handlowego, obejmującego prawo wekslowe, berneńskiemu profesorowi Walterowi Munzigerowi. Gotowy projekt został przedstawiony pod obrady Zgromadzenia Federalnego już w 1864 roku$^{10}$.

W swoich Motywach W. Muniziger podkreślił, że podstawowym założeniem kodeksu jest dążenie do prostoty ${ }^{11}$. Konstrukcja ustawy nie może być jedynie podstawą do prowadzenia naukowych rozpraw, ale ma przede wszystkim umożliwiać korzystanie z treści ustawy przez społeczeństwo. Twórcom projektu szwajcarskiego prawa handlowego przyświecała idea, że jeśli ustawa nie jest popularna i nie może służyć każdej rozumnej osobie do osiągnięcia zamierzonych przez nią celów, okazuje się być „dzieckiem martwym od urodzenia". Dlatego też za podstawę opracowania nie mogły służyć ustawy niemieckie i francuski Code de commerce ${ }^{12}$.

Uzasadniając swoje stanowisko, W. Munziger krótko zanalizował rodzaje czynności handlowych opisanych w niemieckim Kodeksie handlowym z 1861 roku. Jego zdaniem, próba zdefiniowania wszelkich dokonywanych w życiu codziennym czynności handlowych prowadzi jedynie do osiągnięcia wysokiego poziomu zagmatwania ustawy. Rozbudowana klasyfikacja czynności handlowych, której wprowadzenie miało na celu dokonanie precyzyjnego rozdziału pomiędzy czynnościami prawa handlowego i czynnościami cywilnoprawnymi, nie przyczynia się do uporządkowania stosunków prywatnoprawnych, a jedynie ugruntowuje poczucie braku pewności prawnej w społeczeństwie ${ }^{13}$. Szeroki wybór pomiędzy czysto obiektywnymi czynnościami handlowymi, subiektywnymi czynnościami handlowymi z elementem obiektywnym, obiektywnymi z elementem subiektywnym i czysto subiektywnymi czynnościami handlowymi zmusza zarówno uczestników obrotu prawnego jak i praktyków prawa do prowadzenia skomplikowanych analiz normatywnych, mających doprowadzić do odnalezienia odpowiedzi na zasadnicze pytanie: czy w danym stanie faktycznym zastosowanie znajdą przepisy prawa handlowego czy przepisy prawa cywilnego? Dopiero po usunięciu ewentualnych wątpliwości dotyczących natury danego stosunku prywatnoprawnego możliwe stałoby się oddanie sporu wynikłego na tle udziału w danych czyn-

${ }^{9}$ P. Caroni, Der demokratische code unique von 1881. Eine Studie zur ideologischen Beziehung von Sonderrecht und Demokratie, [w:] Das Obligationenrecht 1883-1983. Berner Ringvorlesung zur Jubiläum des schweizerischen Obligationenrecht, pod red. P. Caroniego, Bern-Stuttgart 1984, s. 29.

${ }^{10}$ Ibidem, s. 30.

${ }^{11}$ W. Muniziger, Motive zu dem Entwurfe eines schweizerisches Handlesrechtes, im Auftrage des Tit. Schweiz. Justiz- und Polizeidepartements verfasst von dem Redaktor des Entwurfes, Bern 1865 , s. 5.

${ }^{12}$ Ibidem.

${ }^{13}$ Ibidem, s. 3-4. 
nościach prawnych, pod rozstrzygnięcie odpowiedniego sądu cywilnego bądź gospodarczego (Handelsgericht) ${ }^{14}$. Dlatego też twórcy kodeksu zadali sobie pytanie: czy tworzenie pojęcia czynności handlowych jest w gruncie rzeczy konieczne? Biorąc za przykład swoich rozważań umowę sprzedaży, jako „flagową" czynność handlową, W. Munziger doszedł do wniosku, że sprzedaż pozostanie sprzedażą bez względu na zamiar skorzystania z przedmiotu umowy dla celów osobistych bądź dla celów komercyjnych ${ }^{15}$.

Odstąpienie od stworzenia definicji ,czynności handlowej” nie było jednoznaczne z odrzuceniem przepisów, które znajdowałyby zastosowanie wyłącznie wobec kupców. Rola, jaką pełnią oni w społeczeństwie, jest bowiem szczególna. $Z$ faktu bycia pośrednikiem pomiędzy wytwórcami dóbr a konsumentami wynikają zarówno szersze prawa jak i obowiązki. Mając powyższe na uwadze, postanowiono o oddzieleniu przepisów dotyczących wyłącznie grona kupieckiego, do którego każdy ma swobodny dostęp, od przepisów stosowanych wobec pozostałych uczestników obrotu gospodarczego ${ }^{16}$. Stanowisko to znalazło swój bezpośredni wyraz w poświęceniu trzech (z pięciu) ksiąg kodeksu kupcom, a także literalnie w treści art. 204 kodeksu handlowego: „Postanowienia księgi trzeciej są, z zastrzeżeniem przepisów wyraźnie odnoszących się do obrotu kupieckiego, powszechnie stosowane". Owe wyjątki dotyczyły w szczególności maksymalnej wartości oprocentowania i prawa zastawu ruchomości jako zabezpieczenia roszczeń z tytułu spełnienia świadczenia.

Zdaniem P. Caroniego to właśnie księga trzecia była „centrum” kodeksu. Stosowanie przepisów tej księgi zarówno wobec kupców jak i pozostałych uczestników obrotu było zalążkiem ogólnoszwajcarskiej kodyfikacji prawa cywilnego. Choć marzeniem W. Munizgera było zebranie wszystkich przepisów prawa cywilnego i handlowego pod wspólnym dachem jednego kodeksu, ograniczała go decyzja Rady Związku o skodyfikowaniu wyłącznie przepisów prawa handlowego jako działu prawa najpilniej potrzebującego uwagi.

Pomimo ostrożnego i zachowawczego podejścia twórców kodeksu do kwestii unifikacji prawa cywilnego, projekt ustawy spotkał się z silną krytyką. Swoje negatywne stanowisko szczególnie wyraźnie prezentował konserwatywny prawnik Andreas Heusler. Głosił on potrzebę zdefiniowania pojęcia czynności handlowej i wyraźnego oddzielenia prawa handlowego od cywilnego ${ }^{17}$. Środowiska konserwatywne nadal nie godziły się na rozwiązania prawne, które zagroziłyby suwerenności kantonów w regulowaniu stosunków cywilnoprawnych w swoich granicach administracyjnych. W trakcie dyskusji

\footnotetext{
${ }^{14}$ W. Munziger, Motive..., op. cit., s. 8.

${ }^{15}$ Ibidem.

${ }^{16}$ Ibidem, s. 10.

${ }^{17}$ P. Caroni, Das demokratische..., s. 33.
} 
parlamentarnej pojawiły się także głosy o stanowym charakterze przepisów i uprzywilejowaniu kupców w obrocie gospodarczym ${ }^{18}$.

Jednocześnie z falą krytyki przedstawniono propozycję rozszerzenia prac nad projektem na cały obszar prawa zobowiązań. Trudności w osiągnięciu wspólnego stanowiska co do treści przedstawionego projektu prawa handlowego, jak i brak zgody co do ostatecznego zakresu przyszłej kodyfikacji zadecydowały o nienadaniu projektowi ustawy dalszego biegu na drodze głosowania parlamentarnego. Podjęto za to próbę wprowadzenia w życie przepisów projektu Munzigera drogą konkordatową. W trakcie dwóch konferencji przedstawicieli wszystkich kantonów Szwajcarii w 1867 i 1868 roku ostatecznie odrzucono jednak projekt kodeksu handlowego ${ }^{19}$. Fiasko kodyfikacji było przy tym pozorne. Druga konferencja zakończyła się sporządzeniem wniosku do Rady Konfederacji o zredagowanie powszechnego prawa zobowiązań, które obejmowałyby przepisy odnoszące się bezpośrednio do handlu ${ }^{20}$. Była to chwila narodzin idei code unique.

III. Wprowadzenie idei code unique w życie wymagało przeprowadzenia istotnych zmian kompetencyjnych pomiędzy kantonami i konfederacją. Mogło to nastąpić jedynie drogą zmiany konstytucji. Pierwsza próba uchwalenia zmian konstytucyjnych w 1872 roku, polegająca na nadaniu konfederacji prawa uchwalania ustaw obejmujących wszelkie zagadnienia prawa cywilnego i karnego zakończyła się niepowodzeniem. Dlatego też w konstytucji z 29 maja 1874 roku ograniczono się do nadania konfederacji prawa do uchwalania przepisów dotyczących obrotu gospodarczego (Verkehrsrecht) ${ }^{21}$. Pod tym pojęciem rozumiano wszelkie ,materie prawne związane z handlem i obrotem towarowym"22, innymi słowy: chodziło o prawo skodyfikowania działu prawa prywatnego obejmującego prawo zobowiązań, a także prawo wekslowe i prawo handlowe.

Owa kompetencja Konfederacji została określona mianem Rechtsartikel (artykuł prawa) i pozostawała w ścisłym związku gwarancją wolności handlu i wolności działalności gospodarczej ${ }^{23}$. Wykładnia art. 64 konstytucji z 1874 roku jasno wskazywała, że Konfederacja posiada kompetencje do uchwalania przepisów obejmujących prawo zobowiązań, a zatem wszystkich przepisow dotyczących zobowiązań umownych, pozaumownych i quasi-umownych.

${ }^{18}$ Ibidem, s. 34.

${ }^{19}$ Ibidem, s. 35.

${ }^{20}$ Ibidem, s. 35.

${ }^{21}$ F. Gygi, Die Verfassungsgrundlagen des Schweizerischen Obligationenrecht, [w:] Das Obligationenrecht 1883-1983..., op. cit., s. 9.

${ }^{22}$ K. Sójka-Zielińska, Stulecie kodeksu cywilnego..., op. cit., s. 40.

${ }^{23}$ Art. 31 Konstytucji Konfederacji Szwajcarskiej z 1874 r.: Bundesverfassung der Schweizerischen Eidgenossenschaft vom 29 Mai 1874, tekst dostępny na stronie: http://www.verfassungen.de/ $\mathrm{ch} / \mathrm{verf74-i.htm,} \mathrm{16.08.2013.}$ 
Norma konstytucyjna nie nadała Konfederacji prawa uchwalania przepisów dotyczących prawa rodzinnego, opiekuńczego, spadkowego i rzeczowego. Istotne jest także to, że konstytucja milczy na temat rodzaju norm, którymi miała być uregulowana materia prawa zobowiązań, pozostawiając ustawodawcy swobodę wyboru. Zgodnie ze stanowiskiem doktryny, jak też wynika to z późniejszej praktyki ustawodawczej, konstytucja nadała Konfederacji kompetencję do regulowania prawa zobowiązań obejmującego prawo handlowe z wykorzystaniem norm prawa prywatnego i publicznego ${ }^{24}$.

Z chwilą przyznania Konfederacji prawa regulowania kwestii związanych z powstaniem, trwaniem i wygaśnięciem stosunków zobowiązaniowych powstałych pomiędzy osobami na podstawie umowy, czynu niedozwolonego lub bezpodstawnego wzbogacenia mogły być one regulowane przez kantony wyłącznie w takim zakresie, w jakim prawo federalne w sposób wyraźny lub dorozumiany dopuszczało taką możliwość ${ }^{25}$. Mimo pozorów odebrania kantonom głównej mocy ustawodawczej, odgrywały one nadal znaczącą rolę w obszarze regulowania prawa zobowiązań. Były one bowiem odpowiedzialne za zachowanie porządku prawnego pomiędzy osobami fizycznymi. Zgodnie $\mathrm{z}$ art. 31 konstytucji utrzymano także w mocy kantonalne przepisy dotyczące wykonywania handlu i działalności gospodarczej.

Kantony w wykonaniu swoich obowiązków ustawodawczych dotyczących prawa zobowiązań i prawa handlowego miały prawo wprowadzania ograniczeń służących ochronie zdrowia, życia, obyczajów, moralności, a także spokoju i dobrej wiary w obrocie gospodarczym. Ograniczenia te nie mogły jednak niweczyć istoty wolności handlu i wykonywania działalności, a ich obowiązywanie musiło spełniać warunki przewidziane w konstytucji. Były to: odpowiednia podstawa konstytucyjna do wprowadzenia ograniczeń, ograniczenia musiały być wprowadzane $\mathrm{w}$ interesie publicznym, $\mathrm{z}$ zastosowaniem proporcjonalnych środków i z poszanowaniem zasady równości ${ }^{26}$.

Jeśli w danym obszarze kantony uchwaliły stosowne ograniczenia, skutki naruszenia tych ograniczeń rozpatrywane były z perspektywy federalnego prawa cywilnego. Wyjątkiem były sytuacje, w których prawo federalne nakazywało określić skutki tych naruszeń na podstawie prawa kantonalnego. Dzięki jasnemu i wyczerpującemu podziałowi kompetencji pomiędzy Konfederację i kantony udało się doprowadzić do uchwalenia 14 czerwca 1881 roku jednego z najdoskonalszych dzieł ówczesnej cywilistyki i prawa handlowego, Prawa zobowiązań.

IV. Prawo zobowiązań weszło w życie 1 stycznia 1883 roku. Podstawą jego był kodeks prawa prywatnego opracowany przez J.C. Bluntschliego dla

\footnotetext{
${ }^{24}$ F. Gygi, Die Varfassungsgrundlagen..., op. cit., s. 10.

${ }^{25}$ Ibidem, s. 11.

${ }^{26}$ Ibidem, s. 13.
} 
kantonu Zurychu z 1853/55 roku $^{27}$, kodeks prawa handlowego z 1861 roku opracowany przez W. Munzigera ${ }^{28}$ i tzw. projekt drezdeński (niemiecki kodeks dotyczący prawa zobowiązań) z 1866 roku $^{29}$. Kodeks stanowił zwieńczenie dążeń Munzigera do realizacji idei code unique. Idea zjednoczenia przepisów prawa cywilnego i handlowego w swej doskonałej postaci znalazła finał wyłącznie co do formy, tj. zebrania wszystkich przepisów pod wspólną egidą prawa zobowiązań. W treści przepisów nie dało się jednak obejść, bądź pominąć, szczególnych cech obrotu handlowego, i nie wyszczególnić norm odnoszących się wyłącznie do kupców. Zasada ta dotyczyła przepisów regulujących firmę, zasad księgowości kupieckiej, i pełnomocnictwa handlo$w$ go $^{30}$. Zatem w sensie materialnym prawo zobowiązań (OR) obejmowało zarówno prawo handlowe jak i prawo cywilne, zaś w sensie formalnym w OR traktowano prawo handlowe jako szczególny dział prawa cywilnego.

W swojej oryginalnej postaci prawo zobowiązań obowiązywało do dnia 1 stycznia 1912 roku, kiedy to wraz z wejściem w życie szwajcarskiego kodeksu cywilnego (ZGB) przyjęto jego przepisy w znacząco zmienionej formie. Przede wszystkim prawo zobowiązań stanowiło odtąd piąty tytuł kodeksu cywilnego, przy zachowaniu jego odrębnej numeracji ${ }^{31}$. Rewizja prawa zobowiązań miała na celu dopasowanie jego przepisów do nowo uchwalonego kodesu cywilnego. Polegała zarówno na usunięciu z OR norm przyjętych w ZGB (w szczególności prawo obrotu rzeczami ruchomymi), jak i na nowym ujęciu niektórych materii prawnych ${ }^{32}$. Obszar zmian dostosowujących OR do ZGB obejmował przepisy art. 1-551 OR, tj. przepisy dotyczące prawa zobowiązań i czynności handlowych, pozostawiając rewizję pozostałej części kodeksu na dalszym planie ${ }^{33}$.

Choć prace nad nowym ujęciem przepisów art. 552 i następnych OR powierzono twórcy szwajcarskiego kodeksu cywilnego Eugenowi Huberowi już w $1911 \mathrm{roku}$, to był on w stanie przedstawić pierwszy projekt zmian dopiero po wojnie, w 1919 roku. Projekt Hubera został silnie krytykowany. Zarzucano

${ }^{27}$ A. Bauhofer, Entstehung und Bedeutung des zürcherischen privatrechtlichen Gesetzbuches von 1853-55, osobny wydruk z ZSR, Neue Folge, T. XLVI, z. 1, Basel 1927, s. 74-82.

${ }^{28} \mathrm{~W}$ literaturze podkreśla się, że to właśnie Munziger jest „ojcem” szwajcarskiego prawa zobowiązań; vide: P. Speiser, Erinnerungen and die schweizerische Rechtsvereinheitlichung, ZSR Neue Folge, T. 53, Basel 1934, s. 318; E. Huber, System und Geschichte des Schweizerischen Privatrecht, T. IV, Basel 1893, s. 206.

${ }^{29}$ A. Von Thur, Allgemeiner Teil des Schweizerischen Obligationenrecht, T. I, Tübingen 1924, s. 1.

${ }^{30}$ R. Haab, Einleitung und allgemeiner Überblick über der Revision, [w:] Sieben Vorträge über das neue Obligationenrecht - veranstaltet von der Basler Handelskammer, red. C. Koechlin, Basel 1937, s. 11.

${ }^{31}$ Bundesgesetz betreffend die Ergänzung des Schweizerischen Ziviligesetzbuches (Fünfter Teil: Obligationenrecht)vom 30. März 1911, BB1 1905 II 1, 1909 III 725, 1911 I 845.

${ }^{32}$ A. Von Thur, Allgemeiner Teil..., op. cit., s. 2.

${ }^{33}$ A. Curti, Aktiengesellschaft und Holdinggesellschaft in der Schweiz. Geltendes Recht und Revision, Berlin 1930, s. 1. 
mu zbyt swobodne uregulowanie przepisów dotyczących spółdzielni. Przepisy dopuściły bowiem możliwość obejścia przepisów dotyczących spółki akcyjnej na rzecz założenia pseudo-spółdzielni przedsiębiorców ${ }^{34}$. Podobny opór zrodził się w związku z propozycją osobnego uregulowania spółki okazjonalnej przy jednoczesnym uregulowaniu konsorcjów i syndykatów. Uznano, że regulacje dotyczące spółki okazjonalnej byłyby zbędne, jako że istniały już instytucje prawne, które regulowały stosunku prawne mające doprowadzić do osiągnięcia podobnego celu. Ponadto regulacja spółki okazjonalnej z wysokim prawdopodobieństwem umożliwiłaby uchylenie się od obowiązku zarejestrowania, jaki istniał w stosunku do konsorcjów i syndykatów ${ }^{35}$.

$\mathrm{Z}$ daleko posuniętą rezerwą doktryna odniosła się także do propozycji wydzielenia z części kodeksu, poświęconej spółkom handlowym posiadającym osobowość prawną, przepisów wspólnych dla spółki akcyjnej, spółki komandytowo-akcyjnej, dla spółdzielni i dla spółki z ograniczoną odpowiedzialnością ${ }^{36}$. Jak słusznie podniesiono, różnice w celu, który ma być osiągnięty działalnością tych podmiotów, w szczególności głębokie różnice pomiędzy spółdzielnią i spółką akcyjną wskazywały na błędną kwalifikację tych podmiotów do jednej grupy regulacyjnej. Konstrukcja przepisów OR z projekcie E. Hubera pozwalała na podporządkowanie spółdzielni tym samym zasadom dotyczącym odpowiedzialności za działalność osoby prawnej, które obowiązywały spółkę akcyjną. Ówczesna praktyka sądowa wskazywała na łagodniejsze traktowanie organów spółdzielni przy kwestii odpowiedzialności. Doktryna widziała w tym zagrożenie, że organy spółki mogłyby być wówczas równie łagodnie traktowane jak organy spółdzielni ${ }^{37}$, doprowadzając do swoistego ,ustawowego bezprawia”.

Wobec licznych kontrowersji wokół zaproponowanych przez Hubera rozwiązań prawnych zdecydowano o odrzuceniu projektu rewizji prawa zobowiązań. W związku ze swą chorobą Eugen Huber zrezygnował z dalszej pracy nad projektem. Jego miejsce zajął dr Arthur Hoffman, długoletni adwokat z St. Gallen, mający bogate doświadczenie w prawie handlowym. W grudniu 1923 roku Hoffman przedłożył komisji drugi projekt rewizji prawa zobowiązań. Projekt także spotkał się z krytyką, w związku z czym został przyjęty do dalszego opracowania przez komisję ekspertów, która po ponad czterech latach obradowania przedłożyła trzeci projekt rewizji. Obrady parlamentarne nad projektem prawa zobowiązań trwały osiem lat; ostatecznie 18 grudnia 1936 roku przyjęto ustawę o rewizji tytułu XXIV-XXXIII prawa zobowiązań.

${ }^{34}$ R. Haab, Einleitung..., op. cit., s. 16.

${ }^{35}$ Ibidem, s. 17.

${ }^{36}$ C. Wieland, Aktiengesellschaft und Gesellschaft mit beschränkter Haftung im Entwurf eines revidierten Obligationenrecht, ZSR Neue Folge, T. 41, Basel 1922, s. 115.

${ }^{37}$ Ibidem, s. 116. 
V. Rewizja Prawa zobowiązań z 1936 roku przyczyniła się do usunięcia istotnych luk prawnych i wątpliwości dotyczących niektórych instytucji prawnych, których istnienie pozostawało nie bez znaczenia dla bezpieczeństwa obrotu gospodarczego. Pośród zrewidowanych przepisów znalazły się normy prawne regulujące spółkę akcyjną. Zdefiniowano ją jako osobę prawną posiadającą kwotowo określony kapitał początkowy, określoną liczbę akcji, z których każda ma określoną wartość nominalną ${ }^{38}$. Tym samym przekreślono możliwość emisji akcji określających udział procentowy w kapitale, akcji bez określonej wartości nominalnej, czy akcji pracowniczych ${ }^{39}$. Ustawa przewidziała za to możliwość emisji akcji opiewającej wyłącznie na określoną kwotę pieniężną bez prawa głosu (tzw. Genussschein). Kapitał był jeden, subskrybowany, opłacony, opisany w statucie, definitywny (zmiana wysokości kapitału zakładowego była możliwa w wyjątkowych przypadkach przewidzianych ustawą) i opublikowany ${ }^{40}$.

Prawo zobowiązań z 1881 roku nie dawało jasnej odpowiedzi co do liczby akcjonariuszy potrzebnej do założenia spółki akcyjnej. Nowa ustawa usunęła tę lukę, stanowiąc, że do założenia spółki akcyjnej wymaganych było odtąd przynajmniej trzech akcjonariuszy ${ }^{41}$. Jeśli $\mathrm{w}$ trakcie trwania umowy spółki liczba akcjonariuszy spadłaby poniżej wymaganego poziomu, wówczas sąd mógł rozwiązać spółkę na skutek skargi wniesionej przez innego akcjonariusza lub wierzyciela spółki ${ }^{42}$. Zatem, choć ustawa przewidywała minimalną liczbę trzech akcjonariuszy dla potrzeb powołania spółki do życia, nie przeciwstawiała się skupieniu wszystkich akcji w jednym ręku w przyszłości. Ustawa nie przewidywała przeprowadzenia postępowania o rozwiązanie spółki z powodu niedostatecznej liczby akcjonariuszy z urzędu ${ }^{43}$.

Istotne były także nowe przepisy dotyczące sposobu wpłacania kapitału zakładowego przy symultanicznym zakładaniu spółki akcyjnej. Symultaniczne założenie spółki akcyjnej wymagało notarialnego sporządzenia aktu erekcyjnego podpisanego przez wszystkich akcjonariuszy-założycieli i złożenia przez nich oświadczenia o całościowym opłaceniu kapitału zakładowego $\mathrm{w}$ formie aportu lub $\mathrm{w}$ formie pieniężnej. Jeśli kapitał zakładowy opłacony był w formie pieniężnej, wówczas akcjonariusze nie mogli dokonać wpłaty w dowolnym miejscu na dowolnie wybrane konto, ale w specjalnie do tego celu przeznaczonych depozytach kantonalnych ${ }^{44}$. W akcie erekcyjnym dokumenty

${ }^{38}$ Art. 620 Obligationenrecht.

${ }^{39}$ E. Thalmann, Die Aktiengesellschaft, [w:] Sieben Vorträge..., op. cit., s. 42.

${ }^{40}$ Ibidem.

41 Art. 625 Bundesgesetz betreffend die Ergänzung des Schweizerischen Zivilgesetzbuches (Fünfter Teil: Obligationenrecht) vom 30 März 1911, AS 27317.

${ }^{42}$ Art. 625 Obligationenrecht.

${ }^{43}$ E. Thalmann, Die Aktiengesellschaft, [w:] Sieben Vorträge..., op. cit., s. 43.

${ }^{44}$ Vide: art. 633 i 638 Obligationenrecht. 
potwierdzające dokonanie wpłaty lub wniesienie aportu należało wymienić każdy z osobna, zaś notariusz miał obowiązek poświadczyć, że dokumenty te zostały mu $\mathrm{w}$ oryginale okazane. Powyższe przepisy miały na celu umożliwienie ustalenia odpowiedzialności założycieli spółki ${ }^{45}$, co z szerszej perspektywy przekładało się na zapewnienie bezpieczeństwa obrotu gospodarczego.

Ten sam cel przyświecał ustawodawcy przy uzupełnianiu, a w zasadzie przy tworzeniu niemal całkiem nowego porządku dla spółdzielni. W ustawie z 1881 roku przepisy dotyczące spółdzielni obejmowały 38 paragrafów, które zakładały bardzo daleko idącą swobodę co do sposobu organizacji i działalności spółdzielni. OR w swej oryginalnej postaci zezwalał wszelkim związkom osób na wspólne dążenie do osiągnięcia celów gospodarczych. Szeroko i niejasno sformułowany cel działalności spółdzielni pozwalał z łatwością obchodzić surowsze przepisy dotyczące spółki akcyjnej. Podmioty zorientowane na działalność odpowiadającą profilowi działalności spółki akcyjnej, zamiast dążyć do spełnienia wysokich wymagań dotyczących założenia S.A., powoływały w jej miejsce do życia elastyczniej uregulowaną pod względem prawnym spółdzielnię ${ }^{46}$. Rodziło to dalsze konsekwencje w postaci trudności w orzekaniu wobec spółdzielni i quasi-spółdzielni w sprawach cywilnych, ale także w sprawach podatkowych czy gospodarczych. Sąd musiał brać pod uwagę, czy orzeka wobec rzeczywistej spółdzielni, czy wobec podmiotu, który tylko obchodzi przepisy dotyczące spółki akcyjnej. Praktyka orzecznicza wskazywała na surowsze traktowanie akcjonariuszy spółki w zakresie ich odpowiedzialności za działalność spółki niż członków spółdzielni. Precyzując charakter danego podmiotu i orzekając wobec quasi-spółdzielni, które w rzeczywistości powinny były być spółkami akcyjnymi, surowsze konsekwencje za niezgodne z prawem działanie, sądy dążyły, w granicach swoich ustawowych możliwości, do osiągnięcia równowagi i sprawiedliwości społecznej.

Rewizja 1937 roku „uszczelniła” przepisy dotyczące spółdzielni, zamykając drogę do rażących nadużyć w prawnej organizacji działalności poszczególnych podmiotów obrotu gospodarczego. Różnice w celach, które mają być osiągnięte działalnością spółki akcyjnej i spółdzielni, były od tej pory oczywiste. Założenie spółki akcyjnej miało na celu zgromadzenie kapitału i prowadzenie dzięki niemu określonej działalności gospodarczej, przy czym cel działalności spółki nie był bezpośrednio związany z osobami akcjonariuszy spółki. Z kolei podstawowym założeniem spółdzielni było zorganizowanie grupy osób (z otwartą liczbą członków), po to aby ułatwić im wspólne dążenie do jednego celu ${ }^{47}$. W tym wypadku cel działalności spółdzielni pozostawał w ścisłym, bezpośrednim związku z gospodarczymi potrzebami jej członków.

\footnotetext{
${ }^{45}$ E. Thalmann, Die Aktiengesellschaft, [w:] Sieben Vorträge..., op. cit., s. 45-46.

${ }^{46}$ M. Gerwig, Die Genossenschaft, [w:] Sieben Vorträge..., op. cit., s. 149-151.

${ }^{47}$ Art. 828 Obligationenrecht.
} 
Spółdzielnia, zatem, była formą gospodarczej samopomocy, której zadaniem było wzmocnienie pozycji rynkowej jej członków i ułatwienie im osiągnięcia takich samych celów gospodarczych. Ostatecznie należy podkreślić, że od tej pory spółdzielnia przestała być spółką prawa handlowego, a jej regulacja wręcz przestała należeć do kręgu zainteresowań prawa handlowego ${ }^{48}$.

Założenie spółdzielni było stosunkowo proste i wymagało spełnienia trzech warunków: 1) pisemny statut, 2) posiedzenie założycielskie, które zatwierdzało statut i powoływało organy spółdzielni, i 3) wpis w rejestrze handlowym $^{49}$, na mocy którego spółdzielnia otrzymywała osobowość prawną ${ }^{50}$. Członkami spółdzielni mogły być zarówno osoby fizyczne jak i spółki prawa handlowego. Do założenia spółdzielni wymagano 7 osób.

Rewizja z 1937 roku wprowadziła do Obligationenrecht jeszcze jedno istotne novum, a mianowicie spółkę z ograniczoną odpowiedzialnością. W prawie szwajcarskiem spółka z o.o. ma niemiecką proweniencję ${ }^{51}$. Została ona uregulowana w 28 tytule prawa zobowiązań (art. 772-827).

Podobnie jak w przypadku spółki kolektywnej (Kollektivgesselschaft) do założenia spółki z o.o. wymagano przynajmniej dwóch osób, które sporządzały u notariusza akt erekcyjny, dołączając do niego statut spółki ${ }^{52}$. Powołanie organów spółki nie było konieczne, jako że do działania w imieniu spółki uprawnieni byli wszyscy wspólnicy ${ }^{53}$. W odróżnieniu od spółki kolektywnej, wspólnikami spółka z o.o. mogły być zarówno osoby fizyczne jak i prawne ${ }^{54}$. Spółka uzyskiwała osobowość prawną na skutek wpisu w rejestrze handlowym (art. 783 OR). W rejestrze musieli figurować także wszyscy wspólnicy spółki, nie tylko ci uprawnieni do podejmowania działań w imieniu spółki, jak początkowo wnioskowano ${ }^{55}$.

Spółka z ograniczoną odpowiedzialnośćią nie robiła w Szwajcarii zawrotnej kariery. W pierwszych 10 tygodniach obowiązywania nowej ustawy zarejestrowano tylko 19 spółek z o.o. ${ }^{56}$ Zakładano jednak ożywienie na tym rynku po upływie 5 lat (okresu przejściowego), kiedy spółki akcyjne powinny były dostosować się do nowych przepisów, w tym znacząco podwyższyć kapitał zakładowy ${ }^{57}$. Przewidywano, że kiedy mniejsi przedsiębiorcy nie zdołają zgromadzić wystarczających wkładów pieniężnych zaczną przekształcać się w spółki z o.o. Możliwość taką przewidywała zresztą ustawa w art. 824-826.

${ }^{48}$ M. Gerwig, Die Genossenschaft, [w:] Sieben Vorträge..., op. cit., s. 152-153.

${ }^{49}$ Art. 830 Obligationenrecht.

${ }^{50}$ Art. 838 Obligationenrecht.

${ }^{51}$ V.E. Scherer, Die Gesellschaft mit beschränkter Haftung, op. cit., s. 95-99.

${ }^{52}$ Art. 779 Obligationenrecht.

${ }^{53}$ V.E. Scherer, Die Gesellschaft mit beschränkter Haftung, op. cit., s. 100-101.

${ }^{54}$ Art. 772 Obligationenrecht.

${ }^{55}$ V.E. Scherer, Die Gesellschaft mit beschränkter Haftung, op. cit., s. 103-104.

${ }^{56}$ Ibidem, s. 120.

${ }^{57}$ B I 2. OR Schluss- und Übergangsbestimmungen. 
Spółka akcyjna mogła zostać przekształcona w spółkę z ograniczoną odpowiedzialnością pod warunkiem, że kapitał zakładowy nowej spółki z o.o. nie był niższy aniżeli kapitał spółki przekształcanej, dotychczasowi akcjonariusze mieli zapewnioną możliwość objęcia udziału w spółce do wysokości wartości nominalnej akcji spółki przekształcanej, a udział dotychczasowych akcjonariuszy spółki musiał wynieść minimum dwie trzecie kapitału zakładowego spółki akcyjnej. Oczywiście dotychczasowi akcjonariusze mieli prawo podwyższyć bądź obniżyć swój udział w nowej spółce poprzez wpłacenie wyższego udziału bądź zażądanie wypłaty jego części celem obniżenia swojego udziału w spółce ${ }^{58}$.

Spółka z ograniczoną odpowiedzialnością była odpowiedzią na potrzeby mniejszych, z reguły rodzinnych przedsiębiorstw. Do czasu uchwalenia zmian OR z 1937 roku niemal każdy, kto dysponował jakimkolwiek, nawet niewielkim, kapitałem mógł założyć spółkę akcyjną i w ten sposób uniknąć osobistej odpowiedzialności za działalność spółki ${ }^{59}$. Rewizja z 1937 roku wymogiem podwyższenia kapitału zakładowego S.A. do 50000 franków doprowadziła do likwidacji małych spółek akcyjnych, pozostawiając przy tym mniejszym przedsiębiorcom furtkę do ograniczenia osobistej odpowiedzialności w postaci spółki z ograniczoną odpowiedzialnością. Ustawa przewidywała dla spółek z o.o. minimalną wysokość kapitału zakładowego w kwocie 20000 franków, jednak kwota ta nie stanowiła nadmiernego ciężaru dla mniejszych przedsiębiorstw, a jednocześnie zabezpieczała interesy ewentualnych wierzycieli spółki.

VI. Rewizja z 1937 roku zakończyła prace nad kodeksem cywilnym, nadając normom prawa handlowego nowoczesną postać i kończąc ważny etap unifikacji prawa prywatnego w Szwajcarii. Unifikacja prawa, obejmująca cały obszar Konfederacji Szwajcarskiej, rozpoczęła się i zakończyła debatą nad regulacją prawa handlowego. Niezwykle istotną, a raczej podstawową rolę dla późniejszego kształtu Prawa zobowiązań z 1881 roku, a następnie dla Kodeksu cywilnego z 1912 roku, odegrał projekt kodeksu handlowego z 1861 roku autorstwa $\mathrm{W}$. Munzigera. Ten berneński prawnik przedstawił w swoich „Motywach” podstawowe założenie przyjęte w późniejszej kodyfikacji prawa prywatnego, że rozdział prawa handlowego i prawa cywilnego jest podziałem sztucznym i rodzi nadmierne komplikacje w procesie stosowania. Myśl ta wyznaczyła kierunek dalszych prac kodyfikacyjnych. Choć poszczególne projekty różniły się co do zakresu regulacji czy kształtu poszczególnych instytucji prawnych, to idea o nierozerwalnym związku prawa cywilnego i handlowego w Szwajcarii trwała, pomimo niekiedy zdecydowanych głosów sprzeciwu. Promowanie przez Munzigera pomysłu zredagowania przepisów

\footnotetext{
${ }^{58}$ V.E. Scherer, Die Gesellschaft..., op. cit., s. 123.

${ }^{59}$ Ibidem, s. 99-100.
} 
prawa handlowego bez tworzenia dlań osobnego kodeksu dowodzi przenikliwości umysłu „ojca” Obligationenrecht. Wiedział on, że kultura szwajcarska, oparta na udziale obywateli zarówno w stanowieniu jak i wykonywaniu prawa $^{60}$, wymaga możliwie jasnego i nieskomplikowanego prawa zarówno co do treści jak i formy. Prawdziwość tego twierdzenia nalepiej potwierdza fakt, iż Tytuł V szwajcarskiego Kodeksu cywilnego do dnia dzisiejszego poddano tylko 5 poważniejszym nowelizacjom ${ }^{61}$.

\section{COMMERCIAL LAW IN THE SWISS CODE OF OBLIGATIONS}

\section{Summary}

The Swiss Code of Obligations was a milestone on Switzerland's road to legal unification. The failure of the first supra-cantonal statute would have strengthened decentralizing tendencies and postponed the legal unification on the Confederation level for a long time. The Obligationenrecht (OR) was an exceptional achievement, owing to its lucid and readable structure, simple language, and first and foremost because it gathered civil and commercial law provisions in one codification.

The authors of the Code, while drafting particular provisions of the OR, drew on three sources: the 1853/55 Code of Private Law for the Canton of Zürich, the 1861 Code of Commercial Law and the so-called Dresden Bill (a German code of the law of obligations) of 1866. Although these laws had a tremendous impact on the codification of Switzerland's civil law, the main credit goes above all to 'the father of the Code of Obligations' Walter Munziger. The principles he formulated in the Motives accompanying the draft of the Code of Commercial Law set the direction of further codification work. The work was crowned by the adoption of the Swiss Code of Obligations and later the Civil Code (ZGB), which with time served as the basis for drafting other civil and commercial codifications in Europe and elsewhere.

\section{LE DROIT DU COMMERCE DANS LE CODE DES OBLIGATIONS SUISSE}

\section{Résumé}

L'apparition du code des obligations suisse constitue un événement primordial dans le processus de l'unification juridique en Suisse. L'échec de la première loi su-

${ }^{60}$ K. Sójka-Zielińska, Stulecie kodeksu..., op. cit., s. 49.

${ }^{61}$ BG 25.06.1971 (I, II Art. 1), AS 1971 1465; BG 15.12 .1989 (I, II), AS 1990 802; BG 04.10.1991 (I-III), AS 1992 733; BG 16.12.2005 (I, III), AS 2007 4791; BG 23.12.2011 (I, III), AS 20126679 
pracantonale aurait renforcé l'esprit de la décentralisation et écarté pour longtemps les perspectives de l'unification juridique de la Confédération. L'Obligationenrecht est un ouvrage exceptionnel pour ce qui est sa construction lisible et claire, le langage simple de la loi mais également parce que sous l'égide de la même codification sont réunies les dispositios du droit civil et du commerce.

Pour rédiger les termes du $O R$, les auteurs de la codification ont puisé des renseignements aux trois sources : le code du droit privé pour le Canton de Zürich de 1853-55 , le code du droit du commerce de 1861 et ce que l'on appelle le projet de Dresden (code allemand relatif au droit des obligations) de 1866. Même si ces lois ont une très grande importance pour la codification du droit civil en Suisse, il faut reconnâ̂tre avant tout le mérite du " père du code des obligations », Walter Munziger. Ses hypothèses intégrées dans les Motifs du projet portant le code du droit du commerce indiquent l'axe des chantiers à poursuivre en matière de la codification à poursuivre. Le couronnement de ces travaux était l'adoption du Code des Obligations suisse, ensuite celle du Code civil (ZGB), lequel deviendra, au fur et à mesure, la base de préparation d'autres codifications civiles et commerciales en Europe et dans le monde. 